Julia Neidhardt

Wolfgang Wörndl Editors

Information and

Communication

Technologies in

Tourism 2020

Proceedings of the International

Conference in Surrey, United Kingdom,

January 08-10, 2020

Springer 
Information and Communication Technologies in Tourism 2020 
Julia Neidhardt · Wolfgang Wörndl Editors

\section{Information and}

Communication Technologies in Tourism 2020

Proceedings of the International Conference in Surrey, United Kingdom,

January 08-10, 2020

黛 Springer 


\section{Editors}

Julia Neidhardt

Institute of Information Systems Engineering

TU Wien

Vienna, Austria
Wolfgang Wörndl

Chair of Connected Mobility

TU Munich

Garching, Germany

ISBN 978-3-030-36736-7

ISBN 978-3-030-36737-4 (eBook)

https://doi.org/10.1007/978-3-030-36737-4

\section{(C) Springer Nature Switzerland AG 2020}

This work is subject to copyright. All rights are reserved by the Publisher, whether the whole or part of the material is concerned, specifically the rights of translation, reprinting, reuse of illustrations, recitation, broadcasting, reproduction on microfilms or in any other physical way, and transmission or information storage and retrieval, electronic adaptation, computer software, or by similar or dissimilar methodology now known or hereafter developed.

The use of general descriptive names, registered names, trademarks, service marks, etc. in this publication does not imply, even in the absence of a specific statement, that such names are exempt from the relevant protective laws and regulations and therefore free for general use.

The publisher, the authors and the editors are safe to assume that the advice and information in this book are believed to be true and accurate at the date of publication. Neither the publisher nor the authors or the editors give a warranty, expressed or implied, with respect to the material contained herein or for any errors or omissions that may have been made. The publisher remains neutral with regard to jurisdictional claims in published maps and institutional affiliations.

This Springer imprint is published by the registered company Springer Nature Switzerland AG The registered company address is: Gewerbestrasse 11, 6330 Cham, Switzerland 


\section{Contents}

\section{Social Media}

Adapting to an Emerging Social Media Landscape: The Rise of Informalization of Company Communication in Tourism . . . . . . . 3

Corné Dijkmans, Peter Kerkhof, and Camiel Beukeboom

The Dualistic Model of Passion for Online Travel Community

Activities: The Role of Real-Me and Emotional Loneliness . . . . . . . . 15

Kwang-Ho Lee, Sangguk Kang, and Byeong Cheol Lee

Classification and Visualization of Travel Blog Entries

Based on Types of Tourism . . . . . . . . . . . . . . . . . . . . . 27

Naoki Shibata, Hiroto Shinoda, Hidetsugu Nanba, Aya Ishino,

and Toshiyuki Takezawa

Customer Value Framework and Recommendation Intention:

The Moderating Role of Customer Characteristics in an Online

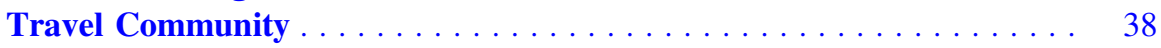

Dandison C. Ukpabi, Heikki Karjaluoto, Sunday Olaleye, and Emmanuel Mogaji

\section{Destinations}

Which Photo Themes Evoke Higher Intention to Visit Switzerland? . .

Meng-Mei Chen and Andreina Irene Ramon Scovino

Influencer Marketing for Tourism Destinations:

Lessons from a Mature Destination

Francisco Femenia-Serra and Ulrike Gretzel

Credibility in Question: Travel Information Adoption Among Chinese

Consumers in Canada and Singapore

$\mathrm{Si} \mathrm{Ru} \mathrm{Li}$, Yi Xuan Ong, and Naoya Ito 
An Efficiency Assessment of DMOs' Facebook Pages:

A Benchmarking Study

Irem Onder, Bozana Zekan, and Nusret Araz

Projected and Perceived Destination Image of Tyrol on Instagram . . . . 103

Adriana Wacker and Aleksander Groth

\section{Recommendation and Decision Making}

The Effects of Group Diversity in Group Decision-Making Process

in the Travel and Tourism Domain

Amra Delic, Judith Masthoff, and Hannes Werthner

Next-POI Recommendations for the Smart Destination Era

David Massimo and Francesco Ricci

From Pictures to Travel Characteristics: Deep Learning-Based

Profiling of Tourists and Tourism Destinations

Mete Sertkan, Julia Neidhardt, and Hannes Werthner

Virtual and Augmented Reality

Enhancing Train Travel with Augmented Reality for Smartphones:

The "Tales on Rails" Project

Heidrun Föhn, Sonja Böckler, Fabio Baumgartner, René Bauer, and Ulrich Götz

Exploring the Impact of Multisensory VR on Travel

Recommendation: A Presence Perspective

Jasmin Hopf, Melina Scholl, Barbara Neuhofer, and Roman Egger

Augmented Reality Applications: The Impact of Usability

and Emotional Perceptions on Tourists' App Experiences

Brigitte Stangl, Dandison C. Ukpabi, and Sangwon Park

\section{Technology}

Impact of Free Wi-Fi on Guest Satisfaction and Price of Properties in Sharing Economy Accommodations

Jacques Bulchand-Gidumal, Santiago Melián-González, and Beatriz González López-Valcárcel

Studying the Factors Influencing Customers' Intention to Use Self-service Kiosks in Fast Food Restaurants 206

Osman Ahmed El-Said and Toleen Al Tall

Pharmabroad: A Companion Chatbot for Identifying Pharmaceutical Products When Traveling Abroad

Boris Ruf, Matteo Sammarco, Jonathan Aigrain, and Marcin Detyniecki 


\section{Hotels}

Exploring the Use of Chatbots in Hotels:

Technology Providers' Perspective .

Dimitrios Buhalis and Emily Cheng Siaw Yen

Brandjacking: The Effect of Google's 2018 Keyword Bidding Policy

Changes on Hotel Website Visibility.

Peter O'Connor

Blockchain Implementation in Hotel Management

$\mathrm{M}^{\mathrm{a}}$ Dolores Flecha-Barrio, Jesús Palomo, Cristina Figueroa-Domecq, and Mónica Segovia-Perez

Self-service Technology Preference During Hotel Service Delivery:

A Comparison of Hoteliers and Customers . . . . . . . . . . . . . . 267 Chun Liu and Kam Hung

Review Helpfulness: The Influences of Price Cues and Hotel Class . . . 280 Erin Yirun Wang, Lawrence Hoc Nang Fong, and Rob Law

\section{Activities}

Semantic Data Models for Hiking Trail Difficulty Assessment

Jean-Paul Calbimonte, Simon Martin, Davide Calvaresi, Nancy Zappelaz, and Alexandre Cotting

Volunteered Geographic Information for Monitoring and Exploring Cycling Activities in the Japanese Nationwide Geographical Space . . . 307 Koun Sugimoto

Author Index 


\title{
Impact of Free Wi-Fi on Guest Satisfaction and Price of Properties in Sharing Economy Accommodations
}

\author{
Jacques Bulchand-Gidumal ${ }^{(\triangle)}(\mathbb{D})$, Santiago Melián-González (D), \\ and Beatriz González López-Valcárcel \\ University Institute for Tourism and Sustainable Economic Development \\ (TIDES), University of Las Palmas de Gran Canaria, Campus de Tafira, \\ 35017 Las Palmas, Spain \\ \{jacques. bulchand, santiago.melian, \\ beatriz.lopezvalcarcel\}@ulpgc.es
}

\begin{abstract}
The purpose of this paper is to analyze the influence of offering free $\mathrm{Wi}-\mathrm{Fi}$ on prices and guest satisfaction of accommodation properties in the sharing economy. To that aim, data on all the listings available on the Airbnb platform in Spain were automatically downloaded. These listings were classified in urban and non-urban ones. Based on a final sample of 74,722 apartments and houses, the impact of $\mathrm{Wi}-\mathrm{Fi}$ and other property amenities was tested using linear regression analysis. Our results show that offering free Wi-Fi has a positive impact on both guest satisfaction and the price of properties. In the case of price, Wi-Fi was the most important amenity. Thus, property owners should seriously consider offering free Wi-Fi because it involves a daily price increase of 16.28 euros, therefore guaranteeing return-on-investment. To our best knowledge, this is the first study to investigate the importance of free $\mathrm{Wi}$-Fi for guest satisfaction in sharing accommodations. It is also one of the first studies to take into consideration non-urban properties since most of the available research has analyzed properties in large cities. Results join the findings about the importance of free Wi-Fi in the traditional accommodation industry, confirming the importance of this technology for the tourism sector.
\end{abstract}

Keywords: Wi-Fi $\cdot$ WLAN $\cdot$ Sharing accommodation $\cdot$ Sharing economy · Peer-to-peer accommodation $\cdot$ Consumer behavior

\section{Introduction}

Sharing or peer-to-peer accommodation is one of the main activities that characterize what is known as collaborative tourism, that is, the set of sharing economy activities that pertain to the tourism industry. The rise of both the sharing economy and collaborative tourism is attributed to several factors, which include consumers' preferences [1], among many others. Consumers' motives for embracing sharing economy services are varied. Among these, individuals frequently mention factors referring to seeking some kind of utility [2]. 
From the guest point of view, there is evidence that sharing accommodation can be a substitute for hotels [3]. In this sense, data show that guests of sharing accommodations value some characteristics that hotels also have, such as the amenities [4] like AC, hair drier and personal items. However, and at the same time, sharing accommodation is also considered an accommodation service characterized by features that are not present in traditional accommodation options. For example, it has been suggested that sharing accommodation guests seek social experiences that are not available in traditional accommodation options [5], like socializing with locals and with other guests.

From the host point of view, property owners freely decide what equipment to offer in their homes. Similarly to what happens in any traditional economic activity, providers seek to offer attractive products that capture the consumer's attention. In fact, on Airbnb, all the properties provide detailed information about their characteristics and amenities, one of which is free Wi-Fi. The importance of this service has been demonstrated in the hotel industry [6]. Nevertheless, there is hardly any evidence about how relevant this amenity is in sharing accommodations, as will be commented in the literature section. It seems obvious that guests will prefer that properties provide free Wi-Fi. Nevertheless, what is not so evident is to what extent the price of properties and guest satisfaction depend on this particular amenity. Therefore, the objective of this research is to analyze the importance of providing free $\mathrm{Wi}-\mathrm{Fi}$ as a property amenity in peer-to-peer accommodations. To that aim, an analysis is done using linear regression analysis based on all the properties offered through Airbnb in Spain considering both the price of properties and guest satisfaction.

The article unfolds as follows. We first present the literature review. The next section contains the research hypotheses, and the following one describes the methodological aspects. Then the results are described, and the conclusions and limitations are presented.

\section{Literature Review}

\subsection{Collaborative Tourism}

Tourism activities that fit under the sharing economy are usually referred to as collaborative tourism [7]. These activities are of different types and involve almost all the areas of tourism, from gastronomy to accommodation, including tourist guides and transportation. Out of these activities, transportation and accommodation are the two areas in which both the sharing economy and collaborative tourism have developed further. In the area of sharing accommodation, there are several digital platforms, out of which Airbnb stands out. It allows anyone who owns a property (the host) to offer it in the platform so that anyone (the guest) looking for a temporarily place to stay can find it. Thus, similarly to other digital platforms, Airbnb is a marketplace in which peers (the host and the guest) can find each other and reach an agreement [8].

Currently, Airbnb has 6 million units in almost every city and every country in the world [9]. It has become widespread due to several reasons, especially cost-savings, amenities available in the units, and the potential for more authentic local experiences [10-12]. 


\subsection{Value in Collaborative Tourism Consumption}

Consumers' use of sharing economy services draws on different motives. In this sense, it has been proved that social benefits (e.g., to have opportunities to start and maintain social relationships, being introduced in local communities) are an important aspect for collaborative tourism consumers [13-15].

At the same time, a more practical or utilitarian component has also been found [16]. In this sense, some authors [10] posit that as it happens with traditional services, in collaborative tourism consumers value the specific characteristics of the service, while [1] found that obtaining utility was the most important factor in the likelihood of choosing peer-to-peer services. In this sense, several works [2, 13, 16, 17] have found that economic benefits (i.e., cost-savings for better value) were an important reason for using sharing economy services. Also, other authors [18] mentioned the product variety available.

\subsection{Sharing Accommodation and Wi-Fi}

Getting a better value is not just an issue of cost. Sharing accommodations include a set of amenities that seek to meet clients' requirements. Air conditioning, access to a kitchen, heating, washers, and Wi-Fi are examples of the amenities that Airbnb hosts can mark when they offer their listings.

Free Wi-Fi has been shown to be an important amenity in the hotel industry. Previous research has found that offering free Wi-Fi was the most important hotel amenity in hotel rating results because it improved hotel ratings by up to 8\% [6]. According to a TripAdvisor report [19] based on more than 44,000 hoteliers and travelers, $46 \%$ of travelers said that free in-room Wi-Fi was considered a must-have amenity. Li et al. identified Internet services as one of the hotel characteristics most appreciated by hotel guests, particularly business travelers and couples [20]. Eriksson and Fagerstrøm found that both Wi-Fi price and Wi-Fi reviews affect consumers' likelihood of booking a hotel [21].

Research has shown that sharing accommodation guests have similar preferences to those of hotels guests. In this regard, [3] showed that in Texas the rise of sharing accommodations negatively affected hotels' economic revenues, suggesting that consumers are increasingly substituting lower-end hotels for Airbnb. Likewise, [22] found that in Barcelona a high density of Airbnb activity has made hotel investment returns on equity fall. [23] found that two-thirds of a sample of Airbnb clients used this platform as a hotel substitute. Therefore, as Akbar and Tracogna [24] thoroughly analyze, some hotel clients find equivalent services in sharing accommodation. Thus, it could be derived that sharing accommodation guests will appreciate free Wi-Fi as hotel guests do and has been proven. However, literature has also mentioned that consumers may have different expectations when staying at sharing accommodations (e.g., social and environmental benefits) than when staying at hotels [13, 15]. Thus, it is not possible to guarantee that free Wi-Fi will be as important for sharing accommodations guests as it is for hotels' guests.

[11] suggested several research questions for the sharing accommodation phenomenon. One of them refers to the importance of the properties' attributes for clients 
and how they compare to those of hotels. Based on previous studies, it is reasonable to hypothesize that for sharing accommodation clients, free Wi-Fi is also an important amenity. Wang and Nicolau [25] analyzed the relevance of different variables in the price of Airbnb's properties. Among them, two property amenities were considered: real beds and wireless Internet. Based on a sample of 33 cities, the authors found a positive and significant effect of both: real beds $(15.5 \%)$ and free Wi-Fi $(9.5 \%)$. However, the focus of this research was the price of properties, and guest satisfaction was not analyzed. Additionally, the aforementioned study was based on listings placed in large cities. Therefore, properties in places such as villages and smaller cities were not included. We believe it would be important to test if the importance of free Wi-Fi is as important outside major urban environments as it is in urban environments. The type of tourists that travel to both types of destinations are different, and their requirements and expectations regarding technological facilities could also be different. It could also be the case that mobile coverage is different in both settings (large urban areas vs. small urban areas, villages and country-side), thus making free Wi-Fi more important in one area than another.

\section{Hypotheses}

In the case of the hotel industry, there is evidence about the importance of offering free Wi-Fi [6]. Literature has also shown the importance of the amenities of properties for the sharing accommodation guests [20]. However, to the best of our knowledge, there is only one empirical study supporting the importance of providing this amenity in sharing accommodations [25]. This research did not consider a key variable for tourism and, especially, for sharing accommodation success, namely, guest satisfaction. In addition, listings out of large cities were not analyzed. In this sense, the literature has extensively recognized the existence of urban tourism [26], with distinctive characteristics from other forms of tourism. Thus, we think it would be valuable to provide more evidence about the extent to which it is relevant for sharing accommodations to offer free Wi-Fi. The relevance of this amenity will be determined by its impact on guest satisfaction and price, respectively, taking into account not only listings in large cities but also listings placed away from these. We propose two hypotheses.

H1. Offering free Wi-Fi positively contributes to sharing accommodations' guest satisfaction.

H2. Offering free Wi-Fi positively contributes to the prices of sharing accommodations.

\section{Methodology}

Spain is an important tourist destination. It was the second most visited country in the world in 2017 [27]. In January 2018, we downloaded from Airbnb data of all the units available in Spain on the platform. For each property, the following data were downloaded: GPS location, average daily rate, type of property (entire apartment and 
houses, private rooms, shared rooms), amenities, capacity, if the host was a superhost, number of reviews, and average guest rating. In order to obtain information from properties actually rented, the criterion of choosing only properties with at least one guest review was used, a similar criterion to that used in previous studies (i.e., [25]). Our initial sample was composed of 98,075 listings, among which 74,722 were entire apartments and houses, 22,819 were private rooms, and 534 were shared rooms. We decided to choose only entire properties because most of the private and shared rooms (more than 90\%) offered free Wi-Fi, which hampered the analysis of this amenity influence. The data about the sample can be found in Table 1.

Table 1. Information about the sample (source: authors)

\begin{tabular}{l|l}
\hline Source & Airbnb \\
\hline Selection criteria & $\begin{array}{l}\text { All entire units, that had received one or more reviews available } \\
\text { in Spain }\end{array}$ \\
\hline Data collection period & January 2018 \\
\hline Data collection method & Automated \\
\hline $\begin{array}{l}\text { Entire apartments and } \\
\text { houses }\end{array}$ & 74,722 \\
\hline Urban and non-urban & 16,191 and 58,531 \\
\hline $\begin{array}{l}\text { With free WiFi and } \\
\text { without }\end{array}$ & 53,308 and 21,414 \\
\hline $\begin{array}{l}\text { Average max.number of } \\
\text { guests }\end{array}$ & 5.22 \\
\hline Average daily rate & 97.89 euros \\
\hline Average rating & 4.75 \\
\hline
\end{tabular}

According to the Spanish Statistical Office [28], the five largest cities in Spain are Madrid (3,182,981), Barcelona (1,620,809), Valencia (787,808), Seville $(689,434)$, Saragossa $(664,938)$ and Málaga $(509,002)$. Thus, our sample is made up of cities smaller than those in the study by Wang and Nicolau [25], where the average size of the 33 cities they considered was close to 2 million people. Table 1 shows that the properties analyzed were located in urban contexts and outside of these locations. We considered a property to be in an urban context if it was within a radius of five kilometers from the center of a city of at least 50,000 people. With this specification, we wanted to determine possible differences from properties that are not located in areas that are usually more in demand by guests. In our sample, the properties' average rate was 97.89 euros (std: 103.78), and their average client rating was 4.75 (std: 0.28 ) on a scale from one to five.

Our alternative dependent variables are average pricing per day in euros and guest satisfaction. The latter was measured by the properties' average client rating, based on a five-star scale with the following values: $1 ; 1.5 ; 2 ; 2.5 ; 3 ; 3.5 ; 4 ; 4.5$ and 5 .

Although our hypotheses revolve around the impact of free Wi-Fi, we decided to include other properties' amenities in order to compare the relative importance of free Wi-Fi. This allows knowing not only whether guest satisfaction depends on free Wi-Fi, 
but whether this amenity is more or less relevant than others, such as a dishwasher, for example. We are not able to posit any hypotheses about the relative importance of the properties' amenities, but this comparison can contribute to better understand the role of free Wi-Fi. The amenities considered as explanatory variables were those included in the Airbnb platform's section where property owners list their services. All of them are treated as dummy variables and consist of the following: $\mathrm{Wi}-\mathrm{Fi}$, air conditioning, heating, kitchen, washer, dishwasher, laptop area, pets, and iron. We decided not to include the amenities kitchen and washer as independent variables in the analysis because they were present in almost all the properties (90\% or more). Apart from Wi-Fi that is the main focus of this research, we also included the other amenities to test the relative importance of $\mathrm{Wi}-\mathrm{Fi}$.

As control variables, the following were taken into consideration: location (urban or non-urban), capacity (maximum number of guests allowed in the property), starting year in Airbnb (2009 to 2017), guest rating (when the price was treated as the dependent variable), and average daily rate (when guest satisfaction was treated as the dependent variable). When guest satisfaction was treated as a dependent variable, the category of Airbnb superhost was also included. The superhost category is awarded every three months by the platform to hosts that meet a series of criteria [29]: high ratings, high demand, low cancellation rate, and high response rate.

The data were analyzed by using linear regression analysis, and significance tests use a significance level of 5\%. Calculations were performed with STATA v14.

\section{Results}

Wang and Nicolau's study showed the relevance of the listings' location. Our results revealed that, except for the kitchen, listings showed significant differences in all the characteristics when the properties' locations are considered (Table 2). Properties located in urban environments are smaller, better equipped (except for the kitchen), and less likely to admit pets than properties located outside a five-kilometer radius from the

Table 2. Properties' characteristics considering their location (source: authors)

\begin{tabular}{l|l|l|l|l}
\hline Characteristics & Non-urban & Urban & Total & Significance \\
\hline Free Wi-Fi & $66.96 \%$ & $87.18 \%$ & $71.34 \%$ & $0.00^{\mathrm{a}}$ \\
\hline Kitchen & $98.18 \%$ & $98.19 \%$ & $98.18 \%$ & n.s. $^{\mathrm{a}}$ \\
\hline Washer & $90.80 \%$ & $91.40 \%$ & $90.93 \%$ & $0.02^{\mathrm{a}}$ \\
\hline Dishwasher & $11.24 \%$ & $12.11 \%$ & $11.43 \%$ & $0.02^{\mathrm{a}}$ \\
\hline Laptop friendly area & $42.36 \%$ & $61.90 \%$ & $46.60 \%$ & $0.00^{\mathrm{a}}$ \\
\hline Pets allowed & $31.03 \%$ & $17.03 \%$ & $28.00 \%$ & $0.00^{\mathrm{a}}$ \\
\hline Air conditioning & $43.10 \%$ & $60.61 \%$ & $46.90 \%$ & $0.00^{\mathrm{a}}$ \\
\hline Heating & $69.08 \%$ & $83.45 \%$ & $72.20 \%$ & $0.00^{\mathrm{a}}$ \\
\hline Iron & $67.29 \%$ & $75.43 \%$ & $69.05 \%$ & $0.00^{\mathrm{a}}$ \\
\hline Capacity (guests) & 5.45 & 4.41 & 5.22 & $0.00^{\mathrm{b}}$ \\
\hline
\end{tabular}

${ }^{\mathrm{a}} \mathrm{Chi} 2$ probability; ${ }^{\mathrm{b}} \mathrm{T}$-test probability. 
center of a city of more than 50,000 people. This result shows that there are differences in the characteristics of urban and non-urban properties, and thus, that it is important to verify the importance of amenities in both types of locations independently.

Table 3 shows that there are no significant differences in guests' ratings depending on the properties' locations. It also indicates that prices and the Airbnb category of superhost show significant differences between urban and non-urban properties. When the price per guest is used instead of the total price of the property, the differences become non-significant.

Table 3. Prices and superhost category considering properties' location (source: authors)

\begin{tabular}{|c|c|c|c|c|c|c|c|}
\hline & \multicolumn{2}{|l|}{ Price } & \multicolumn{2}{|c|}{$\begin{array}{l}\text { Price per } \\
\text { guest }\end{array}$} & \multirow{2}{*}{$\begin{array}{l}\text { Superhost } \\
\%^{\mathrm{c}}\end{array}$} & \multicolumn{2}{|c|}{ Guest rating } \\
\hline & Mean $^{a}$ & Std. & Mean $^{\text {b }}$ & Std. & & Mean $^{\mathrm{b}}$ & Std. \\
\hline Non-urban & 103.48 & 111.45 & 19.13 & 17.18 & $16.64 \%$ & 4.75 & 0.28 \\
\hline Urban & 77.69 & 65.38 & 18.90 & 11.74 & $27.34 \%$ & 4.74 & 0.28 \\
\hline Total & 97.89 & 103.78 & 19.08 & 16.16 & $18.96 \%$ & 4.75 & 0.28 \\
\hline
\end{tabular}

${ }^{\mathrm{a}}$ T-test probability: $0.00 ;{ }^{\mathrm{b}}$ Non-significant; ${ }^{\mathrm{c}} \mathrm{Ch} 2$ probability: 0.00

Hypothesis 1 states that Wi-Fi positively contributes to sharing accommodation client satisfaction. Table 4 collects the results of the linear regressions that analyze

Table 4. Impact of amenities on guest satisfaction ${ }^{\mathrm{a}}$ (source: authors)

\begin{tabular}{|c|c|c|c|}
\hline & Total & Non-urban & Urban \\
\hline $\mathrm{n}$ & 74,722 & 58,531 & 16,191 \\
\hline \multicolumn{4}{|c|}{ Guest satisfaction } \\
\hline Superhost & $0.220^{* * * *}(0.328)$ & $0.205^{* * * *}(0.294)$ & $0.253^{* * * *}(0.408)$ \\
\hline Starting year & $0.026^{* * * *}(0.136)$ & $0.025^{* * * *}(0.132)$ & $0.029^{* * *}(0.148)$ \\
\hline Price & $0.000^{* * * *}(0.088)$ & $0.000^{* * * *}(0.086)$ & $0.000^{* * * *}(0.104)$ \\
\hline Non-urban/urban & $-0.044^{* * *}(-0.068)$ & & \\
\hline Capacity & $-0.000^{\mathrm{ns}}(0.054)$ & $0.000^{\mathrm{ns}}(0.010)$ & $-0.005^{* * *}(-0.035)$ \\
\hline Free Wi-Fi & $0.023^{* * * *}(0.034)$ & $0.025^{* * * *}(0.043)$ & $0.020^{* * *}(0.023)$ \\
\hline Laptop area & $0.014^{* * * *}(0.026)$ & $0.011^{* * *}(0.021)$ & $0.024^{* * *}(0.041)$ \\
\hline Pets & $-0.032^{* * *}(-0.041)$ & $-0.021^{* * *}(-.036)$ & $-0.046^{* * *}(-0.062)$ \\
\hline Air conditioning & $0.003^{\mathrm{ns}}(0.006)$ & $-0.000^{\mathrm{ns}}(-0.001)$ & $0.019^{* * *}(0.033)$ \\
\hline Heating & $0.023^{* * * *}(0.033)$ & $0.025^{* * *}(0.042)$ & $0.013^{*}(0.016)$ \\
\hline Iron & $0.040^{* * * *}(0.066)$ & $0.038^{* * * *}(0.065)$ & $0.046^{* * *}(0.071)$ \\
\hline Dishwasher & $0.047^{* * *}(0.054)$ & $0.045^{* * * *}(0.051)$ & $0.051^{* * * *}(0.060)$ \\
\hline$F$ & 1034.52 & 697.86 & 472.24 \\
\hline$R^{2}$ & 0.17 & 0.15 & 0.26 \\
\hline Adj. $R^{2}$ & 0.17 & 0.15 & 0.26 \\
\hline
\end{tabular}

a Figures in brackets are the variables' standardized coefficients.

*** p: $0.00 ;{ }^{* *} \mathrm{p}<0.01 ;{ }^{*} \mathrm{p}<0.05$ 
guest satisfaction. Figures in brackets are the variables' standardized coefficients. The first column includes all the properties, the second column considers only the properties outside urban environments, and the third column collects properties located in urban areas. In the three regressions, being a superhost is the most important variable for client satisfaction. Regarding the amenities, when all the listings are considered, Wi-Fi positively contributes to client satisfaction, and it is the third most important amenity ( $\beta$ : 0.034), after the iron $(\beta: 0.066)$ and the dishwasher $(\beta: 0.054)$. The same thing is true for the properties located outside urban environments. For properties located in urban areas, the contribution of $\mathrm{Wi}-\mathrm{Fi}$ is also positive, but less important: iron, dishwasher, laptop area, and air conditioning were found to be more important than free Wi-Fi.

Table 5 collects the results of the regressions of property prices and amenities (hypothesis 2). In the three regressions, the capacity (maximum number of guests allowed in the property) is the most important variable in the price. Regarding the amenities, when all the properties are considered, Wi-Fi $(\beta: 0.081)$ is the most important service for the listings' price. Offering Wi-Fi involves an increase in the daily price of 16.28 euros. This increase is higher in the case of non-urban properties (17.22 euros) and lower in the case of urban properties (5.47 euros). The contribution of the second most important amenity (air conditioning, $\beta$ : 0.045 ) entails a price increase of roughly half the previous amount (8.12 euros). For properties located in urban areas, only two amenities showed a significant and positive contribution to the price: heating ( $\beta$ : 0.072) and Wi-Fi ( $\beta$ : 0.032).

Table 5. Impact of amenities on price ${ }^{\mathrm{a}}$ (source: authors)

\begin{tabular}{l|l|l|l}
\hline & Total & Non-urban & Urban \\
\hline $\mathrm{n}$ & 74,722 & 58,531 & 16,191 \\
\hline Price & $18.890^{* * * *}(0.512)$ & $20.189^{* * *}(0.523)$ & $11.980^{* * *}(0.417)$ \\
\hline Capacity & $22.578^{* * *}(0.070)$ & $23.319^{* * *}(0.066)$ & $20.705^{* * *}(0.106)$ \\
\hline Clients rating & $-2.539^{* * *}(0.040)$ & $-2.842^{* * *}(0.042)$ & $-1.563^{* * *}(-0.040)$ \\
\hline Starting year & $-8.935^{* * * *}(-0.043)$ & \multicolumn{2}{|l}{} \\
\hline Non-urban/urban & $16.276^{* * *}(0.081)$ & $17.229^{* * *}(0.082)$ & $5.461^{* * * *}(0.032)$ \\
\hline Free Wi-Fi & $0.403^{\text {ns }}(0.002)$ & $1.694^{*}(0.008)$ & $-4.438^{* * *}(-0.039)$ \\
\hline Laptop area & $-6.979^{* * * *}(-0.034)$ & $-7.808^{* * *}(-0.037)$ & $-4.409^{* * *}(-0.030)$ \\
\hline Pets & $8.122^{* * * *}(0.045)$ & $12.781^{* * *}(0.065)$ & $-6.104^{* * * *}(-0.054)$ \\
\hline Air conditioning & $5.399^{* * *}(0.026)$ & $3.26^{* * *}(0.015)$ & $10.989^{* * *}(0.072)$ \\
\hline Heating & $-4.547^{* * *}(-0.023)$ & $-4.951^{* * *}(-0.023)$ & $-1.908^{\mathrm{ns}}(-0.014)$ \\
\hline Iron & $0.817^{\mathrm{ns}}(0.002)$ & $0.211^{\mathrm{ns}}(0.000)$ & $1.521^{\mathrm{ns}}(0.009)$ \\
\hline Dishwasher & 2228.24 & 1956.94 & 361.71 \\
\hline$F$ & 0.29 & 0.30 & 0.19 \\
\hline$R^{2}$ & 0.29 & 0.30 & 0.19 \\
\hline Adj. $R^{2}$ & &
\end{tabular}

a Figures in brackets are the variables' standardized coefficients. *** $\mathrm{p}: 0.00 ;{ }^{*} \mathrm{p}<0.05$ 


\section{Conclusions}

The main conclusion of this research is that, as in the case of hotels, free Wi-Fi is an important amenity in the sharing accommodation industry. Up to now, it was known that it was relevant for the price of units in cities, while our research shows that it is also important for guest satisfaction. These results are consistent with previous studies cited in the literature review about the importance of free Wi-Fi for hotel guest satisfaction and the substitution of hotels by sharing accommodation options, respectively. Our results also show that free $\mathrm{Wi}-\mathrm{Fi}$ is even more important for properties located outside the urban areas. We believe this may be due to three reasons: first, the fact that urban areas usually have better mobile coverage than other areas; second, some cities in Spain have free public Wi-Fi available in certain areas, especially those with higher tourist interest; third, free Wi-Fi available in most restaurants and bars in major cities which could be used by sharing accommodation guests.

The influence of free $\mathrm{Wi}-\mathrm{Fi}$ on properties' prices confirms the only result about this issue in the sharing accommodation sector [25]. In our research, if we consider the whole sample, Wi-Fi is the amenity with the most impact on price. The same thing is true of properties located outside the urban areas. Along with heating, Wi-Fi is the amenity that was relevant for any property, regardless of its location. Therefore, taking into consideration both the current Internet access prices and that Wi-Fi allows a daily price increase of 16.28 euros, providers who do not offer Wi-Fi are not maximizing their earnings. It must be taken into account that in Spain, the country in which all the properties in this study were located, most Internet providers charge less than 45 euros per month. Thus, with three nights per month of occupation, the Wi-Fi costs would be recovered.

Although it was not the main focus of our research, our results also provide additional interesting findings. First, being located outside the urban areas negatively impacts the property's price, which confirms the finding by Wang and Nicolau [25] who found that the farther the listing is from the city center, the lower its price. Second, we have found that allowing pets contributes in a significant way to guest satisfaction, but negatively: if a property allows pets, the guest satisfaction will be lower. We believe this can be due to the fact that guests travelling without pets will be less satisfied if previous guests have been in a property with pets, thus maybe leaving hair in the furniture or strong smells. Third, regarding air conditioning, and while it was not found to have a significant impact on guest satisfaction when all properties were considered, it did have a significant positive impact when only urban properties were analyzed.

An additional conclusion from the explaining power of the guest satisfaction regressions is that other important factors also influence guest satisfaction. They could be other property aspects not considered in this study (e.g., beds and furniture quality, decoration, room size, building characteristics) and/or aspects of the destination where the properties are located. The finding that staying in a property located in an urban area negatively affects guest satisfaction $(\beta$ : -0.068$)$ may provide a clue. For example, in a sample of guest reviews, previous research [30] found that $45 \%$ of the complaints refer to the environment where the property is located (e.g., street noise, problems with parking in the area). In addition, in the case of the hotel industry, there is evidence that 
the destination's characteristics (e.g., population qualification) significantly affect hotel client satisfaction [31]. We believe that probably a similar result to this one will happen in the case of sharing accommodations.

With regard to the negative role of some of the amenities on price (e.g., iron or air conditioning in urban properties), we do not find any reasonable explanation. It is probably an endogeneity problem of our variables.

\section{Limitations}

Although this study has used a very large sample of more than 74,000 properties, it is not free of limitations, some of which pave the road for future research. The main limitation that we must take into account when using pricing and amenities data that are directly inputted by the hosts, is that hosts may not use revenue management strategies that hotels usually do. There are many systems available to assist individual hosts with the revenue management of their properties; however, these systems are quite popular in markets such as the US, but they are less common in Spain. Thus, we assume that hosts change and manage the prices of their properties, but actually, this may not be the case. Instead, it may be the case that most hosts set a price for the whole year, with small variations for very specific timeframes. Also, some hosts will maybe not take the time to input all the amenities they offer, since they may think that they are not really relevant.

Another limitation is derived from the data we used, that did not allow us to analyze the specific type of property under analysis (e.g., detached house, apartment, isolated house), the type of neighborhood in which it was placed and the demographics of those renting the property.

\section{References}

1. Möhlmann M (2015) Collaborative consumption: determinants of satisfaction and the likelihood of using a sharing economy option again. J Consum Behav 14(3):193-207

2. Tussyadiah I (2015) An exploratory on drivers and deterrents of collaborative consumption in travel. In: Tussyadiah I, Inversini A (eds) Information \& communication technologies in tourism. Springer, Switzerland

3. Zervas G, Proserpio D, Byers JW (2017) The rise of the sharing economy: estimating the impact of Airbnb on the hotel industry. J Mark Res 54(5):687-705

4. Lee D, Hyun W, Ryu J, Lee WJ, Rhee W, Suh B (2015) An analysis of social features associated with room sales of Airbnb. In: Proceedings of the 18th ACM conference companion on computer supported cooperative work \& social computing. ACM, pp. 219-222

5. Belarmino A, Whalen E, Koh Y, Bowen JT (2019) Comparing guests' key attributes of peerto-peer accommodations and hotels: mixed-methods approach. Curr Issues Tour 22(1):1-7

6. Bulchand-Gidumal J, Melián-González S, González López-Valcárcel B (2011) Improving hotel ratings by offering free Wi-Fi. J Hosp Tour Technol 2(3):235-245

7. Dredge D, Gyimóthy S (2017) Collaborative economy and tourism. Springer, Switzerland

8. Bulchand-Gidumal J, Melián-González S (2018) La revolución de la economía colaborativa, Lid, Madrid 
9. Airbnb fast facts: https://press.atairbnb.com/fast-facts/. Accessed 10 July 2019

10. Chen Y, Xie K (2017) Consumer valuation of Airbnb listings: a hedonic pricing approach. Int J Contemp Hosp Manag 29(9):2405-2424

11. Guttentag DA (2015) Airbnb: disruptive innovation and the rise of an informal tourism accommodation sector. Curr Issues Tour 18(12):1192-1217

12. Gutiérrez J, García-Palomares JC, Romanillos G, Salas-Olmedo MH (2017) The eruption of Airbnb in tourist cities: comparing spatial patterns of hotels and peer-to-peer accommodation in Barcelona. Tour Manag 62:278-291

13. Böcker L, Meelen T (2017) Sharing for people, planet or profit? Analysing motivations for intended sharing economy participation. Environ Innov Societal Transit 23(2):8-39

14. Jefferson-Jones J (2016) Shut out of Airbnb: a proposal for remedying housing discrimination in the modern sharing economy. SSRN scholarly paper no. ID 2772078. http://papers.ssrn.com/abstract=2772078. Accessed 10 July 2019

15. Kim J, Yoon Y, Zo H (2015) Why people participate in the sharing economy: a social exchange perspective. In: Proceedings of Pacific Asia conference on information systems 2015, p 76

16. Shaheen SA, Chan ND, Gaynor T (2016) Casual carpooling in the San Francisco Bay Area: understanding user characteristics, behaviors, and motivations. Transp Policy 51:165-173

17. Hamari J, Sjöklint M, Ukkonen A (2016) The sharing economy: why people participate in collaborative consumption. J Assoc Inf Sci Technol 67(9):2047-2059

18. Hawlitschek F, Teubner T, Gimpel H (2016) Understanding the sharing economy-drivers and impediments for participation in peer-to-peer rental. In: Proceedings of the Hawaii international conference on system sciences. HICSS, pp 4782-4791

19. TripAdvisor 6 key travel trends for 2016. https://www.tripadvisor.com/TripAdvisorInsights/ w665. Accessed 10 July 2019

20. Li G, Law R, Vu HQ, Rong J, Zhao X (2015) Identifying emerging hotel preferences using emerging pattern mining technique. Tour Manag 46:311-321

21. Eriksson N, Fagerstrøm A (2017) The relative impact of Wi-Fi service on young consumers' hotel booking online. J Hosp Tour Res 42:1-18

22. Aznar JP, Sayeras JM, Rocafort A, Galiana J (2017) The irruption of Airbnb and its effects on hotel profitability: an analysis of Barcelona's hotel sector. Intangible Capital 13(1):147-159

23. Guttentag DA, Smith SL (2017) Assessing Airbnb as a disruptive innovation relative to hotels: substitution and comparative performance expectations. Int J Hosp Manag 64:1-10

24. Akbar YH, Tracogna A (2018) The sharing economy and the future of the hotel industry: transaction cost theory and platform economics. Int J Hosp Manag 71:91-101

25. Wang D, Nicolau JL (2017) Price determinants of sharing economy based accommodation rental: a study of listings from 33 cities on Airbnb.com. Int J Hosp Manag 62:120-131

26. Ashworth G, Page SJ (2011) Urban tourism research: recent progress and current paradoxes. Tour Manag 32(1):1-15

27. UNWTO tourism highlights 2018 highlights. https://www.e-unwto.org/doi/pdf/10.18111/ 9789284419876. Accessed 10 July 2019

28. Instituto Nacional de Estadística: Official population figures referring to revision of municipal register. http://www.ine.es/dynt3/inebase/en/index.htm?padre=517. Accessed 10 July 2019

29. Airbnb: Superhost: recognising the best in hospitality. https://www.airbnb.co.uk/superhost. Accessed 12 Sept 2910

30. Bulchand-Gidumal J, Melián-González S (2017) Relación entre sostenibilidad y turismo colaborativo a partir de las quejas recibidas en el alojamiento en vivienda vacacional. Cuadernos Económicos 93:91-106

31. Bulchand-Gidumal J, Melián-González S, Lopez-Valcarcel B (2013) A social media analysis of the contribution of destinations to client satisfaction with hotels. Int J Hosp Manag 35:44-47 